\title{
PLANNING AND IMPLEMENTING TOTAL QUALITY MANAGEMENT IN EDUCATION: THE CASE OF CYPRUS
}

\author{
Christos Karageorgos ${ }^{*}$, Athanasios Kriemadis', Antonios Travlos' ${ }^{1}$, Dimitrios Kokaridas ${ }^{2}$ \\ 'Department of Sport Management, University of Peloponnese, Greece \\ 2Department of Physical Education and Sport Science, University of Thessaly, Greece \\ *karagch@sch.gr
}

\begin{tabular}{l}
\hline \hline Article Info \\
\hline Article history \\
Received: August 9, 2020 \\
Revised: November 18, 2020 \\
Accepted: December 8, 2020 \\
\hline
\end{tabular}

Keywords:

Application;

Education;

Evaluation;

Planning;

Total Quality Management.

\begin{abstract}
The transition of TQM from the business field in education started in 1994 to strengthen the humanistic nature of education and improve quality service with the full participation of all involved. Cyprus recognized as a country with highly developed education services and qualitative characteristics that are easily identifiable. However, no studies are published yet concerning the implementation of TQM in Cyprus. The purpose is to examine the design and implementation of TQM at primary and secondary school settings in Cyprus and create a reference point of collecting all partial findings of TQM implementation in Cypriot education. A systematic recording of research included the design and implementation of TQM in education settings using ten electronic databases and keywords including education, TQM and the six factors determining the quality of TQM services. The research included peer-reviewed articles, doctoral theses, and conference abstracts during the last 20 years, leading to future TQM implementation conclusions. Cyprus nowadays focuses on the overall evaluation and implementation of TQM through innovation and quality improvement in education, differentiated and virtual teaching, adapted learning and inclusion of students with disabilities, and hiring new teaching staff that will implement a holistic approach of promoting TQM within school settings.
\end{abstract}

\section{INTRODUCTION}

Total Quality Management (TQM) in education is a relatively new approach of transferring and applying the scientific thinking and practice of management in the education sector (Konidari \& Abernot, 2006), with the academic unit viewed as an entire system that fosters social and professional relationships of all parties involved. TQM has applied to education for the last two decades in most developed countries with optimistic outcomes contributing to education development. When schools in many modern countries transform to meet the quality requirements of the new digital school environment, continuous improvement and involvement of all school stakeholders (students, teachers, parents, and local society) are essential to achieve the main objective of educational quality.

Overall, studies investigated the application of TQM in education at some stage depending on the development, livelihood and educational level of the country or geographic area of the research conducted. In developing countries, researchers explored 
TQM at the level of design and implementation of quality services and improvement strategies, while in most developed countries research focused on the overall evaluation and definition of a roadmap for the implementation of the TQM based on the principle innovation and overall quality improvement (Kettunen, 2012).

In Greece, the investigation of TQM in education settings initially followed a descriptive approach, starting with Koutouzis (1999) and Zavlanos (2003) who interpreted the management application in schools and universities in a theoretical context, followed by Saiti (2012) who explored the extent to which educational leadership in Greece applies the values of Total Quality Management.

Internationally, research has now begun to shift its interest from a simple measurement of quality to educational organizations that follow a holistic approach to promote quality within organizations (Rosa \& Amaral, 2007). In the 21st century, however, there is no single model that provides solutions to teaching, research and services offered at all levels of education (Stensaker et al., 2011). Also, it recognized that there could be no further improvement without the prior description of the current situation and the quality of management practices provided at all education levels in each country.

All countries recognize Cyprus for its educational services, especially the Mediterranean countries, consider Cyprus's education system, a model. The qualitative characteristics of education are easy to identify in Cyprus following their approval by legislation. Practices related to enhancing social and educational inclusion are vital in the context of investigating educational quality. The nature of issues used in the European Foundation for Quality Management and the European Business Excellence Model (EFQM, 1988) has investigated over the last decade. However, in the broader Hellenic area, the literature review reveals that no extensive research has yet to gather all the excerpts of TQM application in Cypriot primary and secondary education.

The purpose of this review article is to examine the design and implementation TQM at primary and secondary school settings in Cyprus, create a reference point of collecting all partial findings of TQM implementation in Cypriot education and provide an overall picture. Understanding the individual factors that promote the TQM application in Cypriot schools can help develop future effective TQM implementation strategies aiming at educational excellence.

\section{METHOD}

The review included a systematic analysis of research that examined the design and implementation of TQM in Cypriot school settings. This analysis took into account that while prospective studies are an essential vehicle for academic debate and exchange (Page, 2008), careful planning is needed when the subject matter is as broad as the TQM so that bias issues do not arise on the timing and significance of the findings of the literature sources investigated (Papaioannou et al., 2010).

IJEMI Vol.2, No.1, January 2021, pp. 1 12 
Thus, articles included in this review met specific criteria related to the participants involved in the education process, the primary and secondary school level, the measurement procedures, the results, and the methodology related to the subject. Special attention paid to the six factors determining TQM in education is leadership, strategic planning, resources, human resource management, processes \& systems and performance measurements.

The process of integrating relevant articles of TQM in education, involved the use of a systematic process of article search in ten online databases, that is, Scopus, Ebscohost, Emerald, Elsevier science, Directory of Open Access Journals, Science Direct, JSTOR, Social Science Research Network, Social Science Citation Index, and Web of Knowledge. The research focused mainly on articles published with a peer review system and postgraduate and doctoral theses written in the Greek and English language since 1994 when the transition of TQM from business to education began to emerge. In this way, this study recorded all research trends in education related to TQM implementation in Cyprus.

In all the online databases keywords used in the Greek and English language, including Total Quality Management or the abbreviation TQM with the words Cyprus, -primary and secondary- education, management, application, administration, effectiveness, performance, efficiency, quality, planning and evaluation. Keywords used included the six TQM dimensions of leadership, strategic planning, resources, human resource management, processes and systems, performance measurements related to excellence and quality in education.

In general, the condition for the inclusion of articles in the review was to meet the following two criteria; first, research should necessarily include the concept of TQM and its six quality elements that define TQM, namely human management resources, strategic planning, leadership, resources and partnerships, processes and performance metrics. Second, the research should include the two compulsory education levels (primary, secondary) and their measurable characteristics in Cyprus case (see Figure 1).

\section{RESULTS}

Integrating relevant articles with the design and implementation of the TQM in the education of Cyprus included a content analysis based on the methodological approach and the purpose of the research. That led to the articles' division into three groups, namely background - theoretical articles, research articles and articles grouped according to the six factors that determine quality in Cypriot education. This process resulted in a "pool" of 24 research articles and 13 review articles in international peer-reviewed journals, 13 Greek conference research articles, 12 Cypriot doctoral theses and one Cypriot postgraduate thesis (Table 1). 


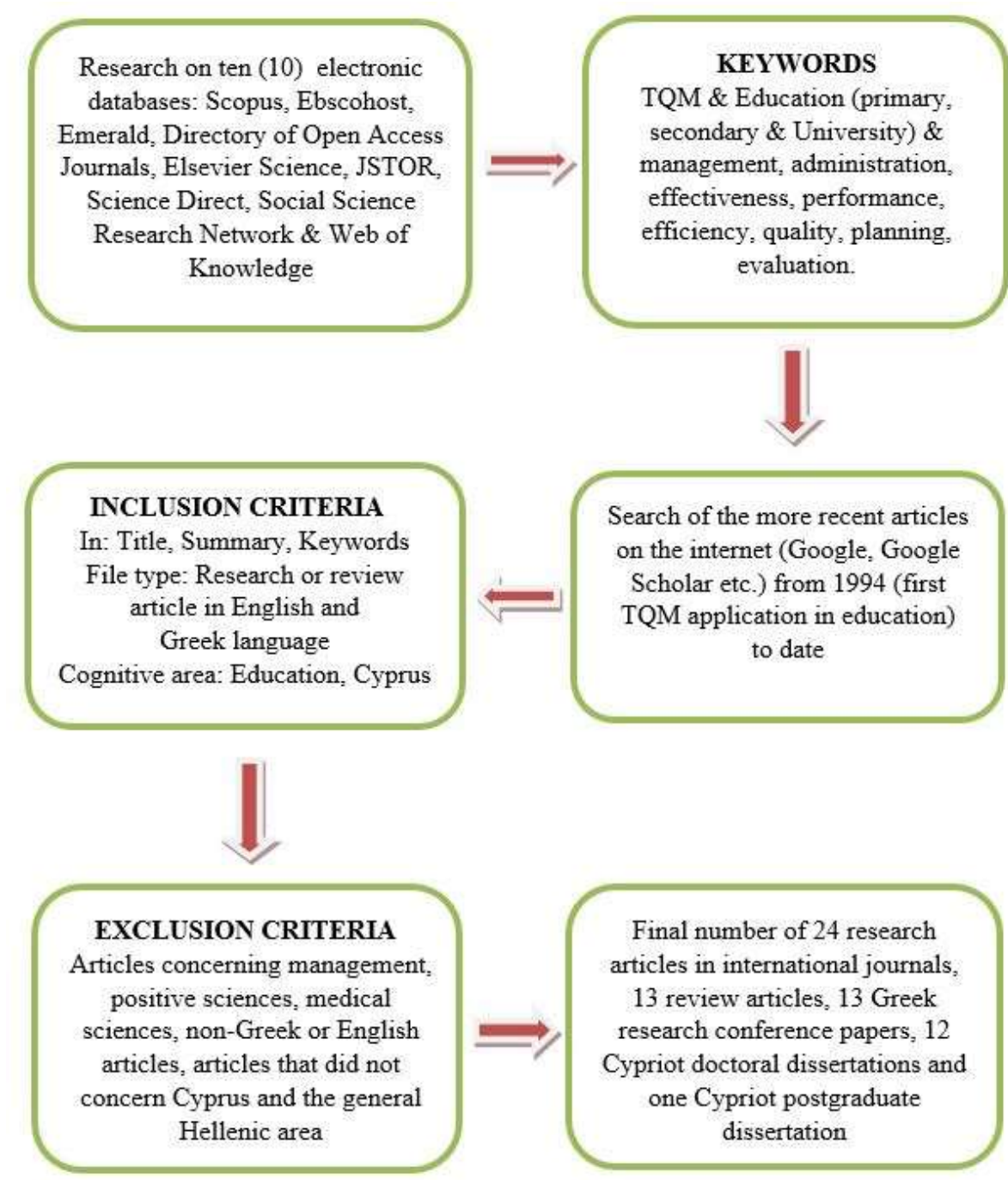

Figure 1. Research design- tracking of articles

Table 1. The original number of articles and theses investigated

\begin{tabular}{|c|c|c|c|c|}
\hline TQM Factors & $\begin{array}{l}\text { Prospective- } \\
\text { Theoretical } \\
\text { Articles }\end{array}$ & $\begin{array}{l}\text { Research } \\
\text { articles }\end{array}$ & $\begin{array}{l}\text { Doctoral and } \\
\text { Postgraduate } \\
\text { Theses }\end{array}$ & Total \\
\hline Leadership & 6 & 10 & $3 P h . D+1$ M.SC & 20 \\
\hline Strategic planning & 5 & 4 & 1 Ph.D & 10 \\
\hline Human Resource Management & & 6 & 3 Ph.D & 9 \\
\hline Procedures & & 11 & 4Ph.D & 15 \\
\hline Resources and partnerships & 2 & 2 & & 4 \\
\hline \multirow[t]{2}{*}{ Performance measurements } & & 4 & $1 \mathrm{Ph} . \mathrm{D}$ & 5 \\
\hline & 13 & 37 & 13 & 63 \\
\hline
\end{tabular}

In brief, the studies examine the design, implementation and evaluation of TQM in Cypriot education as directly related to the six dimensions mentioned in Table 1 that determine this quality. General findings of these articles suggest that although decisions concerning these dimensions as well as curriculum implementation are centrally planned by the Ministry of Education, during the last decade and especially following the Cyprus Education and Training Monitoring Report of 2015, a shift has been noticed from conventional education to 'virtual', 
'interactive' and 'borderless' technologically education within more independent school units. Cyprus Strategy of 2014-2020 seeks now to promote quality and utilization of all human resources involved in the education process and recognize the importance of teaching adaptation and lifelong learning, to support all student population with diverse performance levels and needs by using up-to-date technology and current educational policies within an international framework of cooperation and knowledge exchange with other countries.

\section{DISCUSSION}

As applied to education over the last two decades in most developed countries, Total Quality Management is a relatively new approach with the transfer and application of scientific thinking and management practice in the education sector. The training unit is now one entire system that fosters all stakeholders' social and professional relationships through the application of the six factors that determine quality in education. Based on the corresponding keywords that included combinations of education and TQM concepts, research findings emerged.

\subsection{The Organizational Structure of Cypriot Education}

As for the quality management or assurance system design in primary and secondary education in Cyprus, the Cypriot education system continues to follow a centralized organization attitude. The Ministry of Education and Culture of Cyprus is at the top of this organizational structure that takes all education decisions (Committee of Educational Reform, 2004). The levels of education relate to preschool education, primary education, secondary education and higher education, as in other countries.

The strategic planning of Cypriot education has contributed to an apparent reduction in early school leaving. The design of the Cypriot education system provides access to private and public schools, colleges and universities. Public school attendance is provided free of charge by the state with public education expenses covered by state budget funds. Attending students, with slight public co-finance and private education incomes, pay all tuition fees. Besides, contributions from various private sector entities support both public and private education sectors financially.

\subsection{Special Education}

In Special Education for children with disabilities, support programs exist within the context of inclusive education. Cyprus has revived the 'discourse of values' and re-examined the school's role in the context of co-education of students with and without disabilities and special educational needs (Liasidou, 2012), providing four ways of ranking the least restrictive environments that include full inclusion, public school class with parallel support hours, the particular school with part-time classes, special education schools and home-based services. 
It accomplished with the financial support of special schools and the inclusion legislation of children with disabilities in mainstream education since 1999 (Dimitriou \& Ftiaka, 2012).

The Curriculum now plays a vital role in including children with disabilities (Ftiaka, 2010). Nevertheless, this does not mean that additional measures should not take to ensure equal opportunities, such as individualized teaching when needed (lakovou-Charalambous \& Ftiaka, 2012), the smaller number of children in the classroom, the collaboration between teachers, the training of teachers in disability issues and changing attitudes of all towards disability (Perikleous \& Symeonidou, 2012).

\subsection{Technology Use in Teaching and Learning}

Gradually, conventional education in Cyprus shifts toward 'virtual' education where each school becomes more sensitive to the external environment's effect and vice versa (Russell \& Holkner, 2000). Contemporary Cypriot education requires each school to become an open social system (Anderson, 1999) that uses modern technology and the internet, influenced by the continual social and educational change (Hammond, 2000).

Nevertheless, Cyprus spends only $5 \%$ of its budget on teachers' involvement in relative training seminars. Thus, very few primary and secondary education teachers have trained and willing to incorporate these modern technology approaches into their teaching, which should be a primary goal for the future. Promoting young people with high academic qualifications and training who will develop educational research and create foresight mechanisms for Cypriot education in the future is now the basis of the strategic planning and forecasting of the Cypriot education system by 2020 (Stylianidis \& Passiardis, 2006).

Implementation of this policy follows three planning levels: development/construction, promotion and implementation with the primary objective to redesign schools' operation with increased autonomy and openness toward co-existence with other European schools and societies. The purpose is to reduce student misbehaviour, to focus on teacher evaluation and continuing education, and open up to the Turkish Cypriot community, with Cyprus educational policy - in recent years - introducing the Turkish language into Greek Cypriot education.

Furthermore, Cyprus, while initially lacked ICT facilities, today enjoys a prominent position in ICT use and spends about $95 \%$ of its budget for technological material. In Cypriot schools, all teachers have access to internet-connected computers used in all Curriculum areas (Zembylas \& Vrasidas, 2007).

Nevertheless, teachers need to invest more in teaching, evaluating, and implementing work projects, computers and new teaching methods. Cypriot teachers have implemented differentiated teaching to a limited extent, mostly through personal intuition rather than central planning (Orphanos, 2010). Old teachers with more years of service and experience are not easily familiar with new teaching methods and technology. Thereby, nowadays, there is an obvious need to recruit and appoint highly qualified young teachers with academic credentials through national written exams.

IJEMI Vol.2, No.1, January 2021, pp. 1 12 


\subsection{Modern Educational Policies}

Differentiated teaching and implementation of lifelong learning, therefore, change teachers' attitudes and replace teaching practices with new ones, which is a point of weakness (Konstantinidis, 2012). Since differentiated teaching and lifelong learning added value to the classroom, school, and student environmental levels (Creemers \& Kyriakides, 2010), this, in turn, led to the gradual ending of the existing 'inspection' system by the summer of 2015, since educational inspectors who have been promoting educational policy since 1976 are not familiar with current educational policies.

Another aspect that needs improvement is the psychological support provided to students in Cypriot public education, which is still at an early stage of development. There is vocational guidance but not psychological support in secondary education while school delinquency is still at an early stage as a national policy or research efforts in Cyprus (Kokkinos \& Panayiotou, 2002; Papavasiliou et al., 2006).

Implementation of the new cross-curriculum first piloted in 2011-2012 for multilingual students also needs additional support. The aim is to eliminate nationalistic, mono-cultural and chauvinistic elements in Cypriot education and avoid ideology conflict since the Turkish language in a Greek Cypriot school is frequently perceived as the language of the "enemy", which creates many difficulties in teacher work (Committee of Education Reform, 2004).

However, the policy for monitoring the monitoring system's implementation does not yet exist in the Cypriot education system. Although Cyprus is in a good position regarding the provision and use of learning resources, we cannot yet foresee its performance to provide learning opportunities. Parental involvement in the learning process also lagging significantly (Georgiou, 2015). Also, internal evaluation of the school unit (Papantoniou-Zorpa \& Christofidou, 2012) as one of the most critical effectiveness factors universally acknowledged for its importance, it is not yet observed in Cyprus, nor relevant central regulations that define the content and criteria for external evaluation of public schools are clear (Dimitriou, 2010). In the Cypriot educational reality, evaluation as a procedure, despite its importance in upgrading TQM in education has not yet been developed (Michaelidou, 2010). However, it is necessary that the European Union -of which Cyprus is a member- provide Cyprus with further funding (Michail et al., 2003).

\subsection{Roadmap to Future TQM Implementation}

In educationally developing countries such as Cyprus, research focuses on the overall evaluation and definition of a roadmap for implementing the TQM based on innovation and aims to provide an overall quality improvement through a single systemic framework (Kettunen, 2012). Research internationally is now shifting its focus from a simple provision of educational organizations' quality to a holistic approach of promoting quality within organizations (Rosa \& Amaral, 2007). The same observed in Cyprus based on quality 
performance indicators. In the 21st century, no single model has emerged that provides a solution to all respective areas such as teaching, research and services offered at all education levels (Stensaker et al., 2011). Nevertheless, all recognize that there can be no continuous improvement without paying attention to the quality of management practices at all levels of education and daily, as shown by Cyprus's strategic planning by 2020.

It is relatively difficult to predict how the concept of quality in education will evolve because of a rapidly growing society that becomes 'virtual', 'interactive' and 'borderless' technologically. The concept of quality in education in the future will likely embrace and incorporate these technological trends of the day (Dahlgaard et al., 2015), as is the case with distance education that mainly applied to higher education in Cyprus.

Nevertheless, Cyprus continues to follow the traditional educational model of teaching with limited application of differentiated teaching, 'virtual education' using ICT, promoting diversity and lifelong learning, and recruiting new teachers who will implement the new way of education. Effectiveness and training problems identified, include insufficient training of Cypriot primary and secondary education to integrate ICT use, new student-centred teaching methods and ways of assessing teacher performance. Besides, the development of internal evaluation mechanisms for school units and educational programs despite its importance for securing European funding is not yet visualized (Charalambous \& Karagiorgi, 2006).

Despite efforts, it is a common finding that the modernization of the education system becomes difficult due to its centralized character. School units do not have the autonomy to formulate their educational policy in the context of an open social system of constant change and broader society that leverages ICT. Efficiency and quality in education require improving the poor learning outcomes in crucial skills compared to high education spending, to develop a strategic forecasting model for planning education over time and provide greater autonomy of school units. All of this has led to schools' need to define their policy and for Cyprus to reform its national/state education policy.

The way the concept of school leadership in Cypriot education is understood, which guides to develop the vision of the modern educational reform pursued, is essential for achieving school and learning outcomes that remain relatively low. Regarding school leadership, critical factors associated with improving school performance planning relate to school strategies, staff training, resources, autonomy, climate and policy to foster a professional learning climate through a collaborative - creative model and increase the overall capacity of each school unit. In combination with the human resources management factor, Cyprus' national education policy has implemented the dynamic educational effectiveness model, emphasizing the teaching staff as a primary factor in teaching effectiveness and quality.

Provision of financial resources for pedagogical and administrative needs is still limited. However, Cyprus' participation and cooperation in European programs based on bilateral agreements and the participating States' financial contributions contribute significantly to

IJEMI Vol.2, No.1, January 2021, pp. 1 12 
improving the TQM at all levels of education. Also, Cyprus measures its performance following the trend of educational reform in Europe. The purpose is to improve school and quality education, through a combination of decision-making decentralization, use of educational standards, creation of monitoring systems with the recording of transcripts, more involvement of teaching staff and students as the two key stakeholders, and general internal and external evaluation by developing quality measurement in teaching. Cyprus has an acceptable policy on teaching quality, which is also its top priority. It recognized that it has well-developed education, with the Mediterranean states perceiving its education system as a model.

The Republic of Cyprus Strategy 2014-2020, based on the Cyprus Education and Training Monitoring Report 2015, "seeks to improve the quality and full utilization of the human education resources, the administrative and educational autonomy of the school units, its revised content of education, utilizing the most up-to-date technology and recognizing the diversity and adaptation of the Cypriot educational system to support the entire student population enhancing all kinds of learning" (p. 2). From 2015 onwards, Cypriot strategy implemented intercultural education policy as a vehicle for controlling, interacting and strengthening relationships between people.

Quality improvement in education seems to lead to a 'learner-centered' approach to meet needs, using new technological tools and simplifying the basic TQM principles. It is in this exploration of the integration and collaboration of these three elements of the 'old' with the 'new' (student-centered approach - use of technology to meet student needs - simplifying the application of the basic TQM principles), that proposed for future research directions in Cyprus case.

A deeper understanding of all the factors that promote TQM implementation in Cypriot education also requires future quantitative studies comparing TQM implementation in Cyprus with educational systems of other educationally advanced countries such as Finland, Denmark, England France to identify further improvement steps for the educational system of Cyprus. Besides, more qualitative studies are needed to investigate the perceptions of primary and secondary school teachers profoundly. School principals called upon to implement this significant Cyprus educational reform by 2020 and the Ministry of Education of Cyprus's general principals evaluate the all-important educational project of TQM implementation.

\section{CONCLUSION}

Overall, the design, implementation and evaluation of TQM in Cypriot education directly relate to the six dimensions - leadership (strategic planning, human resources management, processes, resources and partnerships, and finally performance metrics) that determine this quality. Cyprus now focuses on the overall assessment of the TQM implementation based on innovation and quality improvement in education, differentiated and 'virtual' teaching, lifelong learning, highlighting diversity, the inclusion of students with disabilities and hiring new 
teachers to implement the holistic approach to promote quality within schools and life-long learning.

Building a quality structure requires improving the quality of education through a studentcentred approach applied to meet needs, use new technological tools and simplify the application of new technology and education principles to move smoothly toward a modern educational reorganization through the TQM triplet of 'design', 'apply' and 'control'. Future research should investigate such issues to provide a deeper understanding of the design, application, and control of all diverse factors that promote TQM in education settings and facilitate the significant educational reform attempted in Cyprus. Hopefully, this article will create a future reference base that provides an overall picture of TQM application in Cyprus for any researcher who wishes to apply corresponding research in the future.

\section{REFERENCES}

Anderson, W. (1999). Communities in a World of Open Systems. Futures, 31, 457 463.https://doi.org/10.1016/S0016-3287(99)00005-1.

Charalambous, K., \& Karagiorgi, Y. (2006). Information and Communications Technology inservice training for teachers: Cyprus in perspective. Technology, Pedagogy and Education, 11 (2), 197-215.

Committee on Educational Reform. (, 2004). Democratic and Humanistic Education in the European State. Lefkosia: Government Printing Office.

Creemers, B. P., \& Kyriakides, L. (2010). Explaining stability and changes in school effectiveness by looking at changes in the functioning of school factors. School Effectiveness and School Improvement,21 (4), 409-427.

Dahlgaard, J. J., Dahlgaard-Park, S. M., \& Chen, C. K. (2015). Quality excellence in Taiwan: theories and practices. Total Quality Management \& Business Excellence, 1-2. https://doi.org/10.1080/14783363.2014.991205.

Dimitriou, D. (2010, June, 4-5). Comparing the self-assessment mechanisms of the school unit in relation to the improvement of its effectiveness in Cyprus: Prospects for the utilization of the Dynamic Model of Educational Efficiency. $11^{\text {th }}$ Congress of the Cyprus Pedagogical Society, Cyprus [in Greek].

Dimitriou, P., \& Ftiaka, E. (2012, June 8-9). Financial Expenditures and Population of the Special Schools of Cyprus during the period 1990-2010: A quantitative and qualitative investigation. $12^{\text {th }}$ Congress of the Cyprus Pedagogical Society, Cyprus [in Greek].

EFQM. (1988, September 15). European Foundation for Quality Management.http://www.efam.org/.

Ftiaka, E. (2010). Unified Education: One Education for All in a Democratic and Human School. Cyprus Pedagogical Institute: Nicosia [in Greek].

Georgiou, M. (2015). Features of effective educational systems. Doctoral thesis. University of Cyprus [in Greek].

IJEMI Vol.2, No.1, January 2021, pp. 1 12 
Hammond, L. (2000). Futures of Teaching in American Education. Journal of Educational Change, 1, 353-373.

lakovou-Charalambous, M \& Ftiaka, E. (2012, June 8-9). Individualized Curriculum in Secondary Education: Respect for Diversity and Student Preferences or Obstruction? $12^{\text {th }}$ Congress of the Cyprus Pedagogical Society, Cyprus [in Greek].

Kettunen, J. (2012). External and internal quality audits in higher education. The TQM Journal, $24(6), 518-528$.

Kokkinos, M. K., \& Panayiotou, G. (2002). Disturbed behaviour, bullying experience and victimization among juveniles. In M. K. Kokkinos (Ed.), Aggression: proceedings of the 4th Cyprus psychology conference. Nicosia: Cyprus Psychologists' Association.

Konidari, V., \& Abernot, Y. (2006). From TQM to learning organization. Another way for quality management in educational institutions. International Journal of Quality \& Reliability Management, 23(1), 8-26.

Konstantinidis, P. (2012, June 8-9). The views of future primary school teachers on the Sport Education model. $12^{\text {th }}$ Congress of the Cyprus Pedagogical Society, Cyprus [in Greek].

Koutouzis, M. (1999). General principles of management, tourism legislation and organization of employers and collective bodies.Patra: Hellenic Open University [in Greek].

Liasidou A. (2012, June 8-9). The revival of the discourse around values in the era of the crisis of capitalism: The re-examination of the role of the school in the context of inclusive education. $12^{\text {th }}$ Congress of the Cyprus Pedagogical Society, Cyprus [in Greek].

Michaelidou, A. (2010). The future of the Evaluation of Programs in the Cyprus Educational System. In P. Passiardi (Ed.), Evaluation of programs and staff in education. Nicosia: the Open University of Cyprus [in Greek].

Michail, K., Savvidis, I., Stylianidis, M., Tsiakkiros, A., \& Pasiardis, P. (2003). Evaluating Educational Officials: A New Approach. Pedagogical Review, 36, 60-81 [in Greek].

Orphanos, S. (2010, June, 4-5). The practices of the effective teacher in Cyprus. $11^{\text {th }}$ Congress of the Cyprus Pedagogical Society, Cyprus [in Greek].

Page, D. (2008). Systematic literature searching and the bibliographic database haystack. The Electronic Journal of Business Research Methods, 6(2), 171-180.

Papavasiliou, X. V., Andreou-Filimi, A., Dimitriou, D., Mavrikiou, P \& Konstantopoulos, A. (2006, September, 28-30). Juvenile delinquency trends in early and middle adolescence by school pupils in Cyprus. 18th Panhellenic Conference, Child, Health and Culture, Greek Association of Social Pediatrics and Health Promotion, Crete, Greece.

Papaioannou, D., Sutton, A., Carroll, C., Booth, A., \& Wong, R. (2010). Literature searching for social science systematic reviews: consideration of a range of search techniques. Health Information \& Libraries Journal, 27(2), 114-122.

Papantoniou-Zorpa, S., \& Christofidou, E. (2012, June 8-9). A proposal for the internal evaluation of the school unit. $12^{\text {th }}$ Congress of the Cyprus Pedagogical Society, Cyprus [in Greek]. 
Perikleous, S., \& Symeonidou, S. (2012, June 8-9). The challenge of differentiation in the general classroom: A case study. $12^{\text {th }}$ Congress of the Cyprus Pedagogical Society, Cyprus [in Greek].

Rosa, M. J., \& Amaral, A. (2007). A self-assessment of higher education institutions from the perspectives of the EFQM model. In D. F. Westerheijden (Ed.), Quality assurance in higher education: Trends in regulation, translation and transformation (pp. 181-207). Dordrecht: Springer.

Russell, G., \& Holkner, B. (2000). Virtual Schools. Futures, 32, 887-897.

Saiti, A. (2012). Leadership and quality management: An analysis of three key features of the Greek education system.Quality Assurance in Education, 20(2), 110-138.

Stensaker, B., Langfeldt, L., Huisman, J., \& Westerheijden, D. F. (2011). An in-depth study of the impact of external quality assurance. Assessment and Evaluation in Higher Education, $36(4), 465-478$.

Stylianidis, M., \& Passiardis, P. (2006, June 2-3). The future Cypriot school until the year 2020: Towards a model of strategic planning and planning in education. $9^{\text {th }}$ Congress of the Cyprus Pedagogical Society, Cyprus [in Greek].

Zavlanos, M. (2003). Total quality in education. Athens: Stamoulis [in Greek].

Zembylas, M., \& Vrasidas, C. (2007). Listening for silence in text-based, online encounters.Distance Educaducation, 28(1), 5-24. 